\title{
A gyermekszívsebészeti beavatkozás hosszú távú hatásai a pszichológiai fejlődésre
}

\author{
Czobor Nikoletta Ráhel dr.., ${ }^{1}$ - Ocsovszky Zsófia ${ }^{3}$ - Csabai Márta dr. ${ }^{3}$ \\ Róth György dr. ${ }^{1,4}$. Konkolÿ Thege Barna dr. ${ }^{5,6}$. Ablonczy László dr. ${ }^{4}$ \\ Székely Edgár dr. ${ }^{7}$. Gál János dr. ${ }^{8}$ - Székely Andrea dr. ${ }^{8}$ \\ ${ }^{1}$ Semmelweis Egyetem, Doktori Iskola, Budapest \\ ${ }^{2}$ Magyar Honvédség Egészségügyi Központ, Központi Aneszteziológiai és Intenzív Terápiás Osztály, Budapest \\ ${ }^{3}$ Szegedi Egyetem, Általános Orvostudományi Kar, Személyiség-, Klinikai és Egészségpszichológiai Tanszék, \\ Szeged \\ ${ }^{4}$ Gottsegen György Országos Kardiológiai Intézet, Gyermekkardiológiai Osztály, Budapest \\ ${ }^{5}$ Waypoint Research Institute, Waypoint Centre for Mental Health Care, Penetanguishene, Ontario, Kanada \\ ${ }^{6}$ Department of Psychiatry, University of Toronto, Toronto, Ontario, Kanada \\ ${ }^{7}$ Gottsegen György Országos Kardiológiai Intézet, Gyermekszív Központ, \\ Központi Aneszteziológiai és Intenzív Terápiás Osztály, Budapest \\ ${ }^{8}$ Semmelweis Egyetem, Általános Orvostudományi Kar, Aneszteziológiai és Intenzív Terápiás Klinika, Budapest
}

Bevezetés: A korai életkorban szívsebészeti beavatkozáson átesett gyermekek fejlődése során fellépő viselkedési diszfunkciók jelentősen függenek a perioperatív szakban átélt eseményektől.

Célkitüzés: A jelen vizsgálat célja, hogy feltárja a hosszú távú viselkedési változásokat a szívsebészeti beavatkozáson átesett gyermekek körében, és leírja azokat a perioperatív állapotokat, melyek befolyásolhatják a későbbi megküzdési mechanizmusokat.

Módszer: 80, szívmútéten átesett és 62 egészséges kontroll adatait elemeztük. A pszichológiai status felmérése a vizsgálati időszakban a Megküzdési Módok Kérdőív, illetve a Gyermekviselkedési Kérdőív önértékelő kérdéssorának segítségével, míg a perioperatív adatok felvétele az intézeti adatbázisból retrospektíven történt.

Eredmények: Az operált gyermekek körében mind a problémamegoldó, mind az érzelemközpontú megküzdési főskála szignifikánsan alacsonyabb értékeket mutatott az egészséges kontrollcsoporthoz képest. A Gyermekviselkedési Kérdőív önértékelő változata sem internalizáció, sem externalizáció tekintetében nem mutatott szignifikáns eltérést. A hosszú időn át inkomplett keringéssel rendelkező betegek és a kontrollcsoport között szignifikáns eltérést figyeltünk meg az érzelemközpontú megküzdés, illetve a szomatizáció terén, míg az acyanoticus és a kontrollcsoport között a problémaközpontú megküzdés alskáláin (problémaelemzés, alkalmazkodási képesség). A többszöri műtét mind az érzelem-, mind a problémaközpontú megküzdés alacsonyabb fokú aktivációjával összefüggést mutatott, és a hosszú kórházi tartózkodással együtt egy menekülő-elkerülő magatartásforma kialakulásához vezetett.

Következtetés: Úgy tűnik, hogy a kialakult maladaptív viselkedési mechanizmusok jellege jelentősen függ az inkomplett keringés fennállásának időtartamától, a műtétek számától és a kórházi tartózkodás hosszától. A megküzdési stratégiák mozgósítása legfóképp csökkent érzelem- vagy problémaközpontú válaszkészségben, illetve a szomatizációs tendenciák és a menekülő-elkerülő magatartásforma felerősödésében nyilvánul meg.

Orv Hetil. 2020; 161(42): 1787-1796.

Kulcsszavak: gyermekszívsebészet, megküzdés, viselkedés, pszichoszociális fejlődés

\section{Long-term psychological effects of pediatric cardiac surgery}

Introduction: Maladaptive behavioural patterns among children undergoing cardiac surgery can be related to different perioperative states.

Objective: The aim of the present study was to describe the long-term behavioural effects of young children undergoing cardiac surgery and to identify perioperative risk factors associated with the development of coping mechanisms. 
Method: Data of 80 children undergoing cardiac surgery and 62 healthy controls were examined. The psychosocial characteristics were assessed by the Hungarian adaptation of the Ways of Coping Questionnaire and the Youth Self Report, while perioperative data were collected retrospectively from institutional medical records.

Results: Operated children reported significantly poorer coping skills, both in terms of emotion- and problem-focused coping compared to healthy controls. The Youth Self Report showed no significant difference between the surgery and the control groups in terms of internalization and externalization scores. Long-term cyanosis resulted in dysfunctional emotion-focused coping mechanism and somatization, while acyanotic states led to problem-focused difficulties compared to healthy controls. Reoperations and long-term in-hospital stays were related to an escapeavoidant behaviour and a maladaptive emotion-focused coping.

Conclusion: Children undergoing cardiac surgery are at higher risk of developing decreased abilities to mobilize emotion- and problem-focused ways of coping and a higher likelihood of somatization. The duration of incomplete circulation, the number of reoperations and the length of in-hospital stays seem to be the most significant influencing factors regarding future behavioural dysfunctions.

Keywords: pediatric cardiac surgery, coping, maladaptive behaviour, psychosocial development

Czobor NR, Ocsovszky Zs, Csabai M, Róth Gy, Konkolÿ Thege B, Ablonczy L, Székely E, Gál J, Székely A. [Longterm psychological effects of pediatric cardiac surgery]. Orv Hetil. 2020; 161(42): 1787-1796.

(Beérkezett: 2020. március 30.; elfogadva: 2020. május 8.)

\begin{abstract}
Rövidítések
$\mathrm{CBCL}=($ Child Behavior Checklist $)$ Gyermekviselkedési Kérdőív; MMK = Megküzdési Módok Kérdőív; RACHS = $($ Risk Adjustment for Congenital Heart Surgery) a congenitalis szívsebészettel összefüggő rizikó felmérésének rendszere ; TCPC = (total cavo-pulmonary connection) teljes cavopulmonalis kapcsolat; TUKEB = Tudományos és Kutatásetikai Bizottság; VSD = ventricularis septumdefektus; YSR = (Youth Self Report $)$ a CBCL önértékelő kérdéssora;
\end{abstract}

Az elmúlt évtizedekben a szívsebészeti eljárások, a radiológiai képalkotás és diagnosztika, illetve a szívsebészeti technikák fejlődésének köszönhetően a szívfejlődési rendellenességgel született gyermekek több mint 90\%-a megéri a felnőttkort. A betegpopuláció mortalitása ugyanezen időszakban a fent említett okok miatt nagyjából 30\%-kal csökkent [1, 2]. Bár a gyermekek a mútéteket követően fizikailag egészségesen fejlődnek tovább, a perioperatív szakban elszenvedett különböző stresszfaktorok és komplikációk a hosszú távú neurokognitív és pszichés fejlődésre befolyással vannak [3]. A különböző szívfejlődési rendellenességek sebészi korrekciója és az időszakot övező behatások együttese a pszichés morbiditások előfordulási arányát növelik $[4,5]$, a későbbi életminőséget rontják, tanulási nehézségeket és viselkedésbeli devianciákat okozhatnak az érintettekben [6-8]. Ezeknél a gyermekeknél gyakoribb az externalizációs (agresszivitás, deviancia) és internalizációs (szorongás, depresszió, társas kapcsolati nehézségek) problémák kialakulása, illetve a visszahúzódó magatartásformák vagy az emocionális és a szociális gátoltság különböző mértékû formái $[3,9,10]$. A gyermekkori szívmútéteknek a pszichológiai állapotra, életminőségre gyakorolt hosszú távú hatásairól sok ellentmondásos eredmény született napjainkig [10]. Ezek többsége a perioperatív faktorokat is megfigyelés alá vonta azért, hogy a mútéti stressz, illetve a hospitalizáció hosszú távú hatásait felderítse. Ezek a kutatások sok esetben a szívfejlődési rendellenesség típusa mentén végeznek obszervációt, ezzel is specifikusabbá téve azt. Bizonyos anomáliák és mútéttípusok szorosabb összefüggést mutatnak a problémás viselkedésformák megjelenésével, például a pitvari vagy kamrai sövénydefektusok és ezek sebészi zárása, a pulmonalis stenosisok ballonos dilatációja vagy a nagyér-transzpozíciók egy vagy több ülésben történő teljes sebészeti korrekciója [11]. Maga az anomália típusa önmagában is befolyásoló eróvel bírhat a későbbiekre: a jobb-bal sönttel járó defektusok (cyanoticus malformatiók) feltételezhetően nagyobb arányban hajlamosítanak pszichés fejlődési devianciára, illetve kognitív diszfunkcióra a bal-jobb sönttel járó (acyanoticus típusú) anomáliákhoz képest, bár az adatok ezzel kapcsolatban is sok esetben ellentmondásosak [12-14]. Szülői megfigyelések támasztják alá, hogy az operáción átesett gyermekek érzelmi és viselkedésbeli fejlődése eltér az egészségesekétől, a betegség súlyosságától függetlenül. Ezek során figyelték meg, hogy az internalizáló viselkedés, a szomatizáció és a szociális gátoltság gyakoribb azon gyermekeknél, akik hosszú időt töltöttek kórházban, vagy elhúzódó intenzív osztályos kezelésben részesülnek. A kórházi tartózkodás során a gyermek szeparációs szorongást él meg, amely ha tartós, kötődési zavart okozhat. A gyermek pszichéje súlyos, életét veszélyeztető traumaként éli meg (életkortól függően) az anyától való elszakítottságát, ami hozzájárulhat az operált betegcsoport pszichológiai zavarainak magyarázatához. Az érzelmi és szociális fejlődésben kiemelt szerepe van a korai anya-gyermek kapcsolatnak, amely sebészeti beavatkozásokhoz vagy elhúzódó kórházi kezelésekhez köthetően sérülve, befolyásolja a társas kapcsolódást és magatartást. A rövid időtartamú admisszió 
nem, de a hosszú távú vagy az ismétlődő hospitalizáció jelentős mértékű érzelmi deficientiával és viselkedésproblémák kialakulásával járhat [15]. A megküzdési módok nagymértékben befolyásolják az életben maradást és a jóllétet. Így például a közelítő-elkerülő kontinuum [16] mentén kibontakozó elkerülő magatartás rövid távon adaptív lehet, hosszú távon azonban, például egy betegséggel való megküzdés során, rosszabb együttmúködést, lassabb posztoperatív felépülést és korábbi halálozást jelezhet előre [17]. Bár a szakirodalmi eredmények egyértelmû irányba mutatnak, a mindennapi gyakorlatban az utánkövetés során ezen morbiditások szürése nem történik meg, sem diagnosztikai, sem pedig egyértelmú terápiás javaslat nem áll rendelkezésre [3, 18]. Vizsgálatunk elsődleges célja, hogy áttekintse a nemzetközi szakirodalomban leírtak vonatkoztathatóságát a magyarországi gyermekszívsebészeti populációra, vagyis hogy megvizsgálja, hogyan jelennek meg hosszú távon emocionális és viselkedési diszfunkciók ebben a betegcsoportban. Másodlagos célja vizsgálatunknak, hogy összevessük az esetlegesen megjelenő viselkedésváltozások összefüggéseit perioperatív faktorokkal, illetve elemezzük azokat egy egészséges kontrollcsoport pszichológiai statusához viszonyítva, különös tekintettel a megküzdési mechanizmusokra.

\section{Módszer}

A vizsgálat a Tudományos és Kutatásetikai Bizottság engedélyével történt (TUKEB 190/2008; 696-1/2014/ EKU 461/2014) a résztvevők tájékoztatását, valamint írásos és szóbeli beleegyezését követően. A szerzők teljes hozzáféréssel rendelkeztek az adatokhoz, és felelősséget vállaltak azok integritásának megtartásáért és az anonimitás biztosításáért.

Két betegcsoport került vizsgálatra, így összesen 142 gyermek adatait elemeztük. Az operált csoport a 4 éves kor alatt a Gottsegen György Országos Kardiológiai Intézet Gyermekszív Központjában 1995 és 2005 között szívsebészeti beavatkozáson átesett betegeket foglalja magában ( $\mathrm{n}=80$, átlagéletkor $11,5 \pm 3,3$ év). A kontrollcsoportba olyan gyermekek kerültek beválogatásra, akik ambuláns keretek között érkeztek az Intézetbe valamilyen véletlenszerúen fellelt szívzörej miatt, de a kivizsgálás során egészségesnek bizonyultak $(\mathrm{n}=62$, átlagéletkor $11,3 \pm 3,4$ év). A potenciálisan beválogatható betegek jelentős része sajnos a kérdőív hosszára vagy egyéb okra hivatkozva nem kívánt részt venni a vizsgálatban. Egyéb lényeges befolyásoló tényezőnek bizonyult a posztoperatív ambuláns megjelenések gyakorisága, a legtöbb gyermek ugyanis bizonyos idő elteltével, kielégítő egészségi állapota, jólléte miatt már nem vesz részt kontrollvizsgálatokon, így utánkövetésük limitált. Az operált csoport betegei esetén legalább egy alkalommal extracorporalis keringéssel járó beavatkozásnak kellett történnie. A perioperatív adatokat az intézeti adatbázisból nyertük retrospektív módon, míg a pszichológiai felmé- rés tesztek segítségével történt 2013 és 2014 között a kontrollvizsgálatok keretein belül. A kontrollcsoport betegeinek állapotát az első vizsgálat alkalmával mértük fel. Az operált betegek körében az első mütét és a felmérés között átlagosan eltelt idő 6,8 $\pm 2,3$ év volt. Kizárásra kerültek azok, akik súlyos és középsúlyos mentális retardációval járó genetikai kórképpel születtek (Downszindróma, DiGeorge-szindróma) [19], mivel ilyenkor az önkitöltős kérdőívek használata nem lehetséges. Kizárási kritérium volt továbbá a szülői beleegyezés hiánya, a megelőző traumás fejsérülés és a koraszülöttség is. Extrém kis súllyal született beteg (<2500 g) sem az operált, sem a kontrollcsoportban nem volt. A 150 bevont résztvevőből további 8 fó került kizárásra: 3 fó a perioperatív adatok hiányossága miatt, 2 fó nem töltötte ki a pszichológiai kérdőívcsomagot, 3 fó pedig végül nem esett át beavatkozáson. Így összesen 142 személy adatai kerültek feldolgozásra és kiértékelésre.

\section{Klinikai adatok}

A klinikai adatok a centrum adatbázisából kerültek regisztrálásra, melyek egyéb vizsgálatok lefolytatására is alkalmas mennyiségben álltak rendelkezésre mind pre-, mind intra-, mind pedig posztoperatív adatok tekintetében: kor, nem, komorbiditások, diagnózisok, mútéttípusok, mútéti idők, cardiopulmonalis bypass idő, kirekesztési idő, Risk Adjustment for Congenital Heart Surgery (RACHS-) pontszám, a lélegeztetés hossza, a kórházban és intenzív osztályon töltött napok száma. A posztoperatív szövődményeket a Society of Thoracic Surgeons Congenital Heart Surgery adatbázisában definiáltak alapján határoztuk meg [19]. Az intenzív osztályos és kórházi tartózkodás idejének feltüntetésekor az átlagértékekbe a reoperációk mútéti idejét és az azokat követő kórházi tartózkodást is belekalkuláltuk.

\section{A pszichológiai status felmérése/ Méróeszközök}

Az ambuláns találkozások alkalmával az alábbi tesztek kerültek felvételre a gyermekek és szüleik körében:

\section{Gyermekviselkedési Kérdöiv önértékelo" kérdéssora (Child Behavior Checklist/YSR Youth Self Report)}

A Gyermekviselkedési Kérdőív [20] önértékelő (Youth Self Report - YSR) változata - éppúgy, mint a szülői (CBCL ) - egy 6 alskálából álló kérdőív, melynek részét képezik a társas kapcsolati problémákra (I), a szorongásra és depresszióra (II), a szomatizációra (III), a figyelemzavarra (IV), a deviáns viselkedésre (V) és az agresszív viselkedésjellemzőkre (VI) irányuló kérdéscsoportok. Az I. és a II. alcsoport együttesen az internalizációs, az V. és a VI. alcsoport pedig az externalizációs tüneteket méri. 
Vizsgálatunkban a magyar populációra adaptált verziót használtuk [21]. A figyelemzavarokra vonatkozó IV. alskála eredményeivel egy külön közleményünk foglalkozik.

\section{Megküzdési Módok Kérdőín (MMK)}

A Lazarus által készített Megküzdési Módok Kérdőív a személy stresszel való megküzdését hivatott mérni. Az eredeti kérdőív 68 tételből áll, és Lazarus elméletének megküzdési dimenziói mentén sorolja 7 csoportba az egyes tételeket, amelyek két főskálában (probléma- és érzelemfókuszú megküzdési mód) összegződnek [22]. Az egyes alskálák összértékét az alájuk tartozó tételek pontszámainak összege adja ki. A főskálák pontszámát az őket kitevő alskálák pontszámainak összege adja. A jelen tanulmányban a Kopp és Skrabski által rövidített és adaptált, 22 tételes magyar verziót használtuk [23]. Az első 3 alskála a problémafókuszú (problémaelemző, kognitív átstrukturálás/célorientált cselekvés, alkalmazkodási képesség), míg a többi 4 az érzelemközpontú (érzelmi indíttatású cselekvés, pozitív átértékelés, menekülés-elkerülés, szociális támasz keresése) megküzdési stratégiákat méri [24].

\section{Statisztikai elemzés}

Az analízis az SPSS 24. segítségével történt (IBM Corp., Armonk, NY, USA). A szignifikanciaszintet minden elemzés esetén a p<0,05 szintjén állapítottuk meg. A leíró statisztika elkészítése után kétmintás t-próbák segítségével kerültek összevetésre a csoportok. Elsődlegesen az operált és a kontrollcsoport teszteredményei, másodlagosan pedig a mütött klinikai csoportban mutatkozó különbségek (komplikációk tekintetében, úgymint: reoperáció, halasztott sternumzárás, cyanoticus állapot) kerültek kiértékelésre. A kórházi és intenzív osztályos tartózkodás hossza olyan vágópontok mentén került elemzésre, melyek, feltételezéseink szerint, a pszichés statust befolyásolhatják. Módszeres léptetéssel figyelve a szignifikanciaszint változását, 5, 10 és 20 napnál húztuk meg a modellhatárokat. Az 5 és 20 napos vágópontok eredményeit mutatjuk be [25]. A hatásméreteket a Cohen-féle d-érték mutatja [26].

\section{Eredmények}

Összesen 142 (80 szívsebészeti beavatkozáson átesett és 62 egészséges kontroll)gyermek adatait elemeztük. Az átlagéletkor a tesztfelvétel idején $11,5 \pm 3,4$ év volt a mútött ( $47,5 \%$ fiú, $52,5 \%$ lány) és $11,3 \pm 3,5$ a kontrollcsoportban (58\% fiú, $42 \%$ lány) szignifikáns eltérés nélkül. A különböző szívfejlődési rendellenességek típusai és azok százalékos megoszlása az alábbiak szerint alakult: septumdefektusok ( $\mathrm{n}=15 ; 18,75 \%)$, billentyúhibák $(\mathrm{n}=$ $15 ; 18,75 \%)$, coarctatio aortae billentyúhibával és/vagy septumdefektussal $(\mathrm{n}=5 ; 6,25 \%)$, nagyér-transzpozíció $(\mathrm{n}=9 ; 11,25 \%)$, teljes cavopulmonalis anastomosis képzését igénylö vitiumok ( $\mathrm{n}=20 ; 25 \%)$, Fallot-tetralógia $(\mathrm{n}=7 ; 8,75 \%)$, egyéb $(\mathrm{n}=9 ; 11,25 \%)$.

A demográfiai és perioperatív jellemzők az 1. táblázatban láthatók. Az átlagos RACHS-pontszám 2,5 \pm 0,8 volt, az intenzív osztályos átlagos tartózkodási idő 5,8 \pm 6,7 nap, a kórházban eltöltött átlagos idő pedig 18,7 \pm 10,6 nap. A 80 operált gyermek közül 38 került mútétre cyanosissal járó, 42 pedig acyanoticus szívhibával. A 80 beteg összesen 150 mütéten esett át. 34 beteg esetén került sor tervezett reoperációra. A statisztikai elemzésbe a tervezett reoperáción átesettek kerültek bevonásra. 14 betegnél $(17,5 \%)$ volt szükséges halasztott sternumzárás.

A cyanoticus állapot befolyásoló hatásának vizsgálata során két, a fejlődési rendellenesség alapján homogénnek tekinthető betegcsoport került meghatározásra az operált csoporton belül. A legsérülékenyebb betegcsoportot az egykamrás keringéssel, illetve a TCPC kialakítását

1. táblázat Az operált és a kontrollcsoport demográfiai adatai, illetve a sebészeti esetek perioperatív jellemzői

\begin{tabular}{|c|c|c|c|c|c|}
\hline & \multicolumn{2}{|c|}{ Kontroll $(\mathrm{n}=62)$} & \multicolumn{2}{|c|}{ Operált $(\mathrm{n}=80)$} & \multirow[t]{2}{*}{ p-érték } \\
\hline & Átlag/N & Szórás/\% & Átlag/N & Szórás/\% & \\
\hline $\begin{array}{l}\text { Átlagéletkor (év) } \\
\text { a tesztfelvételkor }\end{array}$ & 11,3 & 3,45 & 11,55 & 3,4 & 0,66 \\
\hline $\begin{array}{l}\text { Átlagéletkor az } 1 \text {. } \\
\text { mütét idején (hó) } \\
\mathrm{n}=80\end{array}$ & $\mathrm{n} / \mathrm{a}$ & $\mathrm{n} / \mathrm{a}$ & 5,2 & 5,7 & \\
\hline $\begin{array}{l}\text { Átlagéletkor a } 2 \text {. } \\
\text { mütét idején (hó) } \\
\mathrm{n}=38\end{array}$ & $\mathrm{n} / \mathrm{a}$ & $\mathrm{n} / \mathrm{a}$ & 43,3 & 37,5 & \\
\hline $\begin{array}{l}\text { Átlagéletkor a } 3 \text {. } \\
\text { mütét idején (év) } \\
n=23\end{array}$ & $\mathrm{n} / \mathrm{a}$ & $\mathrm{n} / \mathrm{a}$ & 6,7 & 3,4 & \\
\hline $\begin{array}{l}\text { Átlagéletkor a } 4 \text {. } \\
\text { mütét idején (év) } \\
\mathrm{n}=9\end{array}$ & $\mathrm{n} / \mathrm{a}$ & $\mathrm{n} / \mathrm{a}$ & 9,3 & 6,5 & \\
\hline \multicolumn{6}{|l|}{ Nem } \\
\hline Fiú & 36 & 58 & 42 & 52,5 & \multirow[t]{2}{*}{0,32} \\
\hline Lány & 26 & 42 & 38 & 47,5 & \\
\hline $\begin{array}{l}\text { ITO-tartózkodás } \\
\text { (nap) }\end{array}$ & \multicolumn{2}{|c|}{$\mathrm{n} / \mathrm{a}$} & 5,8 & 6,7 & - \\
\hline $\begin{array}{l}\text { Kórházi } \\
\text { tartózkodás (nap) }\end{array}$ & \multicolumn{2}{|c|}{$\mathrm{n} / \mathrm{a}$} & 18,7 & 10,6 & - \\
\hline Mütéti idő (perc) & \multicolumn{2}{|c|}{$\mathrm{n} / \mathrm{a}$} & 203,6 & 87,6 & - \\
\hline ECC-idő (perc) & \multicolumn{2}{|c|}{$\mathrm{n} / \mathrm{a}$} & 107,4 & 66,4 & - \\
\hline $\begin{array}{l}\text { Aortakirekesztési } \\
\text { idő (perc) }\end{array}$ & \multicolumn{2}{|c|}{$\mathrm{n} / \mathrm{a}$} & 50,8 & 45,4 & - \\
\hline RACHS & \multicolumn{2}{|c|}{$\mathrm{n} / \mathrm{a}$} & 2,5 & 0,8 & - \\
\hline $\begin{array}{l}\text { Lélegeztetés } \\
\text { hossza (óra) }\end{array}$ & \multicolumn{2}{|c|}{$\mathrm{n} / \mathrm{a}$} & 58,4 & 85,5 & - \\
\hline
\end{tabular}

ECC $=$ extracorporalis keringés; ITO = intenzív terápiás osztály; $\mathrm{n} / \mathrm{a}=$ nincs adat; RACHS = a congenitalis szívsebészettel összefüggő rizikó felmérésének rendszere 
igénylő vitiummal rendelkezők alkotják (TCPC-csoport), akik egy korai palliatív megoldást követően 2-3 éves korukig cyanoticus állapotban várnak a végleges korrekciós mútétre. A cyanosis időtartama ilyenkor az 1 évet meghaladja. A 2 . csoportba az izolált VSD-vel diagnosztizáltak kerültek, akiknél cyanoticus állapot biztosan nem állt fenn (acyanoticus csoport).

\section{Megküzdési Módok Kérdőív (MMK)}

Az operált és a kontrollcsoport megküzdésre és viselkedésre vonatkozó eredményeit a 2. táblázat mutatja. A MMK az operált csoportban a problémamegoldó fóskálán $(\mathrm{p}=0,002)$, azon belül is fơként a problémaelemzésre $(\mathrm{p}=0,007)$ és az alkalmazkodásra $(\mathrm{p}<0,001)$ vonatkozóan szignifikánsan alacsonyabb értékeket mutatott a kontrollcsoporthoz képest. Az érzelemközpontú megküzdési főskálán ( $\mathrm{p}=0,026)$ szintén szignifikánsan alacsonyabb eredmények születtek a mútéten átesettek körében, leginkább az érzelmi egyensúly keresésének tekintetében $(\mathrm{p}<0,001)$. A teszteredmények szignifikáns eltérést mutattak a TCPC- és a kontrollcsoport között a társastámasz-keresés alskáláján $(\mathrm{p}=0,017)$, illetve az érzelemközpontú megküzdés főskáláján $(p=0,03)$. Az acyanoticus és a kontrollcsoport között szignifikáns különbségek mutatkoztak a problémaközpontú megküz- dés több pontján (problémaelemzés, $\mathrm{p}=0,013$; alkalmazkodási képesség, $\mathrm{p}=0,027$ ) és az érzelemközpontú megküzdés érzelmi egyensúlykeresésre vonatkozó részén, csökkent szinteket okozva az operált alcsoport körében (3. táblázat). A reoperáción átesettek szignifikánsan alacsonyabb pontszámot értek el a problémaközpontú megküzdési főskála minden alskáláján (problémaelemzés, $\mathrm{p}=0,035$; kognitív átstrukturálás/célorientált cselekvés, $\mathrm{p}=0,003$; alkalmazkodás, $\mathrm{p}<0,001$; problémamegoldó föskála, $\mathrm{p}<0,001)$, illetve az érzelemközpontú megküzdés érzelmi egyensúlykeresés $(\mathrm{p}=0,003)$ és társastámasz-keresés $(\mathrm{p}<0,001)$ alskáláján, míg magasabbat a menekülés-elkerülés $(\mathrm{p}=0,002)$ alskálán (4. táblázat). Mind a 4 napot meghaladó gépi lélegeztetés $(4,9 \pm 1,8$ vs. $3,1 \pm 0,88 ; \mathrm{p}=0,007)$, mind a halasztott sternumzárás az elkerülő megküzdést erősítette fel (halasztott $M=5,5 \pm 1,41$ vs. nem halasztott $M=3,0 \pm$ 1,75; p<0,001). Az 5 napnál hosszabb intenzív osztályos tartózkodás magasabb pontszámokat eredményezett a problémaelemzésre $(5,7 \pm 2,4$ vs. $3,9 \pm 2,5 ; \mathrm{p}=0,006)$ és a menekülő-elkerülő magatartásra ( $4,2 \pm 1,7$ vs. $2,7 \pm$ $1,8 ; \mathrm{p}=0,002)$ vonatkozóan. További megfigyelésünk, hogy a 20 napot meghaladó kórházi tartózkodás szintén a menekülés-elkerülés tüneteit $(4,3 \pm 1,8$ vs. $3,1 \pm 1,8$; $\mathrm{p}=0,02)$ erősítette fel szignifikánsan.

2. táblázat |Az operált és az egészséges betegcsoport megküzdési és viselkedéses jellemzői

\begin{tabular}{|c|c|c|c|c|c|c|}
\hline & \multirow{2}{*}{\multicolumn{2}{|c|}{$\begin{array}{c}\text { Operált }(\mathrm{S}) \\
\mathrm{n}=80\end{array}$}} & \multirow{2}{*}{\multicolumn{2}{|c|}{$\begin{array}{c}\text { Kontroll (K) } \\
\mathrm{n}=62\end{array}$}} & \multirow[t]{3}{*}{ p-érték } & \multirow[t]{3}{*}{ Cohen-d } \\
\hline & & & & & & \\
\hline & Átlag & Szórás & Átlag & Szórás & & \\
\hline \multicolumn{7}{|l|}{ Megküzdési Módok Kérdöív } \\
\hline Problémamegoldó megküzdés & 10,7 & 8,1 & 14,5 & 6,1 & 0,002 & 0,32 \\
\hline Problémaelemzés & 3,4 & 3,1 & 4,6 & 2,1 & 0,007 & 0,07 \\
\hline Célorientált cselekvés/kognitív átstrukturálás & 4,5 & 3,8 & 5,2 & 2,9 & 0,258 & 0,18 \\
\hline Alkalmazkodás & 2,8 & 2,4 & 4,7 & 2,3 & $<0,001$ & 0,12 \\
\hline Érzelemközpontú megküzdés & 9,6 & 6,9 & 13,6 & 4,9 & 0,026 & 0,31 \\
\hline Érzelmi indittatású cselekvés & 2,4 & 2,6 & 2,1 & 2,1 & 0,57 & 0,15 \\
\hline Menekülés-elkerülés & 2,3 & 1,9 & 2,8 & 1,6 & 0,081 & 0,02 \\
\hline Érzelmi egyensúly keresése & 2,3 & 1,9 & 3,8 & 1,9 & $<0,001$ & 0,21 \\
\hline Társas támasz keresése & 2,7 & 2,2 & 3,1 & 1,5 & 0,243 & 0,18 \\
\hline \multicolumn{7}{|l|}{ A Gyermekviselkedési Kérdöív önértékelo" változata } \\
\hline Internalizáció & 4,9 & 4,3 & 4,3 & 4,4 & 0,49 & 0,09 \\
\hline Szociális kapcsolati zavarok & 2,7 & 2,5 & 2,2 & 2,2 & 0,27 & 0,13 \\
\hline Szorongás/depresszió & 2,3 & 2,3 & 2,2 & 2,7 & 0,86 & 0,05 \\
\hline Szomatizáció & 1,5 & 2,1 & 1,4 & 2,1 & 0,67 & 0,07 \\
\hline Externalizáció & 4,6 & 4,4 & 3,8 & 3,9 & 0,24 & 0,14 \\
\hline Deviáns viselkedés & 1,4 & 1,6 & 1,2 & 1,6 & 0,49 & 0,22 \\
\hline Agresszív viselkedés/impulzivitás & 3,1 & 3,1 & 2,6 & 2,7 & 0,25 & 0,14 \\
\hline Összprobléma-pontszám & 9,5 & 11,2 & 12,3 & 9,2 & 0,37 & 0,17 \\
\hline
\end{tabular}


3. táblázat $\mid$ A cyanoticus vitiummal járó állapotok és a pszichológiai teszteredmények kapcsolata. Az elemzéshez elkülönítésre került egy hosszú távú cyanoticus állapottal és inkomplett keringéssel járó (TCPC képzését igénylő vitiumok), illetve egy homogén acyanoticus betegcsoport (izolált VSD)

\begin{tabular}{|c|c|c|c|c|c|c|c|c|}
\hline & $\begin{array}{l}\text { TCPC } \\
(\mathrm{n}=20)\end{array}$ & $\begin{array}{l}\text { Kontroll } \\
(\mathrm{n}=62)\end{array}$ & \multirow[b]{2}{*}{ p-érték } & \multirow[b]{2}{*}{ t-érték } & $\begin{array}{c}\text { VSD } \\
(\mathrm{n}=15)\end{array}$ & $\begin{array}{l}\text { Kontroll } \\
(\mathrm{n}=62)\end{array}$ & & \\
\hline & \multicolumn{2}{|c|}{ Átlag/Szórás } & & & \multicolumn{2}{|c|}{ Átlag/Szórás } & p-érték & t-érték \\
\hline \multicolumn{9}{|l|}{ Megkiüdési Módok Kérdőív } \\
\hline Problémamegoldó megküzdés & $13,6 / 5,3$ & $14,5 / 6,1$ & 0,76 & $-0,31$ & $10,5 / 7,1$ & $14,5 / 6,1$ & 0,11 & 1,72 \\
\hline Problémaelemzés & $5,0 / 1,3$ & $4,6 / 2,1$ & 0,42 & 0,84 & $2,5 / 2,3$ & $4,6 / 2,1$ & 0,013 & $-2,79$ \\
\hline $\begin{array}{l}\text { Célorientált cselekvés/kognitív } \\
\text { átstrukturálás }\end{array}$ & $4,6 / 2,5$ & $5,2 / 2,9$ & 0,62 & $-0,51$ & $5,2 / 3,4$ & $5,2 / 2,9$ & 0,89 & 0,13 \\
\hline Alkalmazkodás & $4,0 / 2,0$ & $4,7 / 2,3$ & 0,48 & $-0,74$ & $2,7 / 1,8$ & $4,7 / 2,3$ & 0,005 & $-3,13$ \\
\hline Érzelemközpontú megküzdés & $10,4 / 4,4$ & $13,6 / 4,9$ & 0,03 & 1,96 & $10,7 / 4,8$ & $11,9 / 4,6$ & 0,53 & $-0,64$ \\
\hline Érzelmi indíttatású cselekvés & $2,6 / 1,7$ & $2,1 / 2,1$ & 0,52 & 0,67 & $2,6 / 2,7$ & $2,1 / 2,1$ & 0,53 & 0,65 \\
\hline Menekülés-elkerülés & $3,0 / 1,8$ & $2,8 / 1,6$ & 0,73 & 0,36 & $2,8 / 1,7$ & $2,8 / 1,6$ & 0,84 & 0,20 \\
\hline Érzelmi egyensúly keresése & $3,0 / 1,7$ & $3,8 / 1,9$ & 0,33 & $-1,05$ & $2,0 / 1,6$ & $3,8 / 1,9$ & 0,003 & $-3,31$ \\
\hline Társas támasz keresése & $4,9 / 1,5$ & $3,1 / 1,5$ & 0,017 & 2,99 & $3,2 / 1,9$ & $3,1 / 1,5$ & 0,79 & 0,27 \\
\hline \multicolumn{9}{|c|}{ A Gyermekviselkedési Kérdöív önértékelo" változata } \\
\hline Internalizáció & $5,3 / 4,3$ & $4,3 / 4,4$ & 0,45 & 0,77 & $5,9 / 5,1$ & $4,3 / 4,4$ & 0,34 & 0,99 \\
\hline Szociális kapcsolati zavarok & $2,5 / 2,3$ & $2,2 / 2,2$ & 0,61 & 0,52 & $3,5 / 2,9$ & $2,2 / 2,2$ & 0,18 & 1,40 \\
\hline Szorongás/depresszió & $2,7 / 2,4$ & $2,2 / 2,7$ & 0,40 & 0,85 & $2,5 / 2,5$ & $2,2 / 2,7$ & 0,73 & 0,34 \\
\hline Szomatizáció & $2,9 / 3,2$ & $1,4 / 2,1$ & 0,049 & 2,05 & $1,4 / 1,6$ & $1,4 / 2,1$ & 0,95 & 0,06 \\
\hline Externalizáció & $3,9 / 3,7$ & $3,8 / 3,9$ & 0,83 & 0,22 & $4,8 / 4,2$ & $3,8 / 3,9$ & 0,37 & 0,92 \\
\hline Deviáns viselkedés & $1,3 / 1,6$ & $1,2 / 1,6$ & 0,78 & 0,27 & $1,6 / 1,8$ & $1,2 / 1,6$ & 0,49 & 0,69 \\
\hline Agresszív viselkedés/impulzivitás & $2,5 / 2,6$ & $2,6 / 2,7$ & 0,88 & 0,15 & $3,2 / 3,0$ & $2,6 / 2,7$ & 0,39 & 0,89 \\
\hline Összprobléma-pontszám & $15,0 / 11,5$ & $12,3 / 9,2$ & 0,35 & 0,96 & $16,2 / 12,3$ & $8,1 / 9,9$ & 0,29 & 1,09 \\
\hline
\end{tabular}

TCPC = teljes cavopulmonalis kapcsolat; VSD = ventricularis septumdefektus

\section{Gyermekviselkedés (CBCL)}

A CBCL önértékelő kérdőív (YSR) összpontszáma alapján nem volt szignifikáns különbség a mütéten átesett és a kontrollcsoport egyénei között sem az internalizáció, sem az externalizáció tekintetében. A cyanoticus állapot befolyásoló hatásának vizsgálata során megfigyeltük, hogy a TCPC-csoport szignifikánsan magasabb pontszámokat ért el a szomatizációra vonatkozó alskálán ( $\mathrm{p}=$ 0,049 ) a kontrollcsoporthoz képest. Az acyanoticus és a kontrollcsoport között nem találtunk szignifikáns különbséget (3. táblázat). Az operált csoporton belül az YSR szorongás-depresszió alskáláján szignifikánsan magasabb pontszámot értek el azok, aki 5 napnál rövidebb ideig tartózkodtak intenzív osztályon $(1,9 \pm 1,7$ vs. 3,2 $\pm 2,9 ; \mathrm{p}=0,017)$, vagyis a rövid idejü intenzív osztályos jelenlét az internalizációs tüneteket erősítette fel jelentősen.

\section{Megbeszélés}

Megfigyeléses vizsgálatunk azt mutatta, hogy a 4 éves kor alatt szívmütéten átesett gyermekek megküzdési stratégiái és pszichés adaptációja több ponton eltér a kontrollcsoportétól. A beavatkozáson átesetteknél mind az érzelemközpontú, mind a problémamegoldó megküzdés mozgósítása terén nehézséget tapasztaltunk. Bár az internalizációs és externalizációs viselkedés összességében nem különbözött jelentős mértékben, tendenciában az operált gyermekekre az externalizáló magatartás, azaz a belső feszültségek külvilág felé való vetítése volt jellemzőbb. A hosszú kórházi tartózkodás szignifikánsan nagyobb mértékü szomatizációs tendenciát, illetve a menekülő-elkerülő magatartásforma előtérbe kerülését okozta a rövidebb ideig hospitalizált gyermekekhez képest. A fent említettek miatt igyekeztünk feltárni azokat a faktorokat, melyek a két csoport közti eltéréseket befolyásolhatták. A két, cyanosis szempontjából homogénnek tekinthető operált betegcsoport vizsgálata során megfigyeltük, hogy a hosszú időn át inkomplett keringéssel élő gyermekeknél fóleg az érzelemközpontú megküzdés, míg az acyanoticus vitium miatt műtétre kerülőknél a problémaközpontú megküzdés aktiválódása, valamint az alkalmazkodás jelenti a fó problémát. Egyéb befolyásoló faktornak tünik a reoperációk magas száma, ugyanis a többszörös mútéten átesett egyéneknél a csökkent problémamegoldó megküzdésen felül megjelent egy szignifikánsan magasabb menekülő-elkerülő típusú 'coping' és egy érzelmi egyensúlyt kereső megküzdés is. 
Az egyszeri, illetve többszörös mútéten átesett gyermekek pszi chológiai teszteken elért eredményei

\begin{tabular}{|c|c|c|c|c|}
\hline & \multicolumn{4}{|c|}{ Többszörös mútét } \\
\hline & $\begin{array}{c}\text { Igen } \\
\mathrm{n}=34\end{array}$ & $\begin{array}{c}\mathrm{Nem} \\
\mathrm{n}=46\end{array}$ & & \\
\hline & \multicolumn{2}{|c|}{ Átlag/Szórás } & p-érték & Cohen- $\mathrm{c}$ \\
\hline \multicolumn{5}{|c|}{ Megküzdési Módok Kérdöív } \\
\hline $\begin{array}{l}\text { Problémamegoldó } \\
\text { megküzdés }\end{array}$ & $8,4 / 8,2$ & $14,9 / 5,4$ & $<0,001$ & 0,087 \\
\hline Problémaelemzés & $2,4 / 3,1$ & $4,2 / 2,5$ & 0,035 & 0,45 \\
\hline $\begin{array}{l}\text { Célorientált cselekvés/ } \\
\text { kognitív átstrukturálás }\end{array}$ & $2,8 / 3,5$ & $5,8 / 2,9$ & 0,003 & 0,68 \\
\hline Alkalmazkodás & $1,6 / 2,1$ & $4,9 / 1,9$ & $<0,001$ & 1,32 \\
\hline $\begin{array}{l}\text { Érzelemközpontú } \\
\text { megküzdés }\end{array}$ & $5,8 / 7,1$ & $12,5 / 4,2$ & $<0,001$ & 0,23 \\
\hline $\begin{array}{l}\text { Érzelmi indíttatású } \\
\text { cselekvés }\end{array}$ & $1,4 / 2,3$ & $2,6 / 2,2$ & 0,083 & 0,369 \\
\hline Menekülés-elkerülés & $2,9 / 1,3$ & $1,3 / 1,6$ & 0,002 & 0,711 \\
\hline $\begin{array}{l}\text { Érzelmi egyensúly } \\
\text { keresése }\end{array}$ & $1,4 / 1,9$ & $3,2 / 1,8$ & 0,003 & 0,683 \\
\hline Társas támasz keresése & $1,6 / 2,2$ & $3,8 / 1,4$ & $<0,001$ & 0,893 \\
\hline \multicolumn{5}{|c|}{ A Gyermekviselkedési Kérdōí önértékelo" változata } \\
\hline Internalizáció & $4,2 / 4,9$ & $4,3 / 3,7$ & 0,94 & 0,041 \\
\hline $\begin{array}{l}\text { Szociális kapcsolati } \\
\text { zavarok }\end{array}$ & $2,1 / 2,3$ & $2,4 / 2,3$ & 0,56 & 0,122 \\
\hline Szorongás/depresszió & $2,2 / 3,1$ & $1,9 / 1,9$ & 0,69 & $-0,082$ \\
\hline Szomatizáció & $1,7 / 2,8$ & $1,3 / 1,9$ & 0,54 & $-0,125$ \\
\hline Externalizáció & $2,6 / 2,5$ & $4,8 / 5,2$ & 0,051 & 0,419 \\
\hline Deviáns viselkedés & $1,0 / 0,9$ & $1,6 / 1,6$ & 0,026 & 0,352 \\
\hline $\begin{array}{l}\text { Agresszív viselkedés/ } \\
\text { impulzivitás }\end{array}$ & $1,7 / 1,9$ & $3,2 / 3,8$ & 0,08 & 0,363 \\
\hline Összprobléma-pontszám & $9,2 / 7,7$ & $6,8 / 7,0$ & 0,27 & 0,228 \\
\hline
\end{tabular}

Ez utóbbiak leginkább érzelmi fókuszú megküzdést előfeltételeznek.

A sebészeti technikák és a különböző terápiás eljárások gyors fejlődése ellenére a szívsebészeti mútéten átesett gyermekek későbbi pszichés fejlődése az eddigi tapasztalatok szerint elmaradhat, vagy másként alakulhat a nem beteg gyermekekéhez viszonyítva. Bár eddig nem sikerült egyértelmû összefüggést találni a szívfejlődési rendellenességek és a pszichológiai kimenetel között, a korai diagnosztika és hosszú távú szoros utánkövetés elengedhetetlen része a posztoperatív rehabilitációnak [3, 10]. Bizonyos vizsgálatok konkrét anomáliatípusok esetén találtak rosszabb posztoperatív életminőséget, például Fallot-tetralógia vagy pitvari septumdefektus [27], míg mások heterogén módon, a komplex fejlődési rendellenességeket nevezték meg ugyanezen következmény okaként [28]. Utánkövetések igazolták, hogy - a rendellenességek komplexitásától és jellegétől függetlenül - a szívfejlődési anomália miatt beavatkozáson átesett betegpopuláció körében magasabb a szomatizációs reakciók, a figyelemzavarok és az internalizációs problémák előfor- dulása [29]. Fallot-tetralógiás cyanoticus és kamrai sövénydefektusos acyanoticus gyermekek esetén hasonlóan eltérő internalizációs és externalizációs tüneteket figyeltek meg az egészségesekhez képest [11]. Szintén betegségjellegtől függetlenül szociális nehézségek és érzelmi diszfunkcionális attitűdök jellemezték az operált gyermekeket évekkel a beavatkozást követően [30]. Bár eltérô mértékben ugyan, de mind a társas kapcsolatok, mind a problémamegoldó megküzdési mechanizmusok nehezítettek lehetnek a beavatkozásokat követően [31, 32].

$\mathrm{Az}$ általunk vizsgált, különféle fejlődési rendellenességgel mútétre kerülő betegek körében hasonlókat tapasztaltunk anomáliától és komplexitástól függetlenül. Úgy túnik ugyanis, hogy mind az érzelemközpontú, mind a problémamegoldó megküzdési mechanizmusok csökkent effektivitással múködnek az operált egyénekben. Addicionális megfigyelésünk, hogy a 20 napot meghaladó kórházi tartózkodás növeli a leginkább a szomatizációs tünetegyüttes incidenciáját. Az externalizációs magatartásformák (impulzív vagy deviáns viselkedés, agresszió) hosszú ideig kórházban kezelt gyermekekben alacsonyabb szintünek mutatkoztak a jelen vizsgálatban, és sokkal inkább teret nyertek az internalizációs tendenciák diszfunkciói (szorongás, depresszió, társas kapcsolati zavarok) annak ellenére, hogy összességében egyik viselkedésdeviáció sem ért el szignifikánsan magasabb vagy alacsonyabb mértéket az egészséges csoport egyéneihez viszonyítva. Ez utóbbi tendenciára irodalmi adatok eddig nem álltak rendelkezésre.

Számos vizsgálat kereste a választ arra, hogy a fent említett különbségek mögött milyen tényezők, illetve esetlegesen modifikálható faktorok és események állhatnak. A legalapvetőbb feltevés az inkomplett keringés (cyanoticus állapot) hosszú távú következményeire épít. Ez az állapot tünik ugyanis a legmeghatározóbbnak a későbbi fejlődés szempontjából, értve ezen nemcsak a fizikális, de a neuropszichológiai vonalat is. A jobb-bal sönttel járó, cyanoticus szívhibák, mint a nagyér-transzpozíció vagy a hypoplasiás bal szívfél szindróma által reprezentált, többé-kevésbé homogén betegcsoport esetén találtak az egészségesektől eltérő, nagyobb mértékü viselkedésbeli maladaptációkat [33]. De bármely cyanoticus vitium esetén megfigyeltek már jelentősebb előfordulást figyelemhiány, depresszió, szorongásos zavar (internalizáló forma) vagy deviáns viselkedés terén (externalizáló forma) $[30,34]$. A fent említett vizsgálatok a hosszú távú inkomplett keringéses állapotot jelölik meg elsődleges okként a későbbi pszichés problémákra vonatkozóan [35], azonban számos olyan megfigyelést közöltek, melyek hasonló kimenetelról számolnak be acyanoticus defektusok esetén is, beleértve a későbbi életminőségcsökkenést és az érzelmi vagy problémamegoldó mechanizmusok deficitjét $[11,36]$. Saját populációnkban a cyanoticus állapot fennállása esetén, illetve annak hiányában is tapasztaltunk viselkedésbeli eltéréseket az egészséges gyermekekhez viszonyítva. Az 1 évet meghaladó inkomplett keringéssel rendelkező gyermekeknél 
(TCPC-csoport) az érzelemközpontú megküzdést találtuk gyengébbnek mindamellett, hogy a szomatizációs tünetek előfordulása jóval magasabb mértéket ért el a kontrollcsoporthoz képest. Az acyanoticus csoportban szintén megfigyelhetô volt megküzdési nehézség, ám esetükben főleg a problémaközpontú stratégiák (problémaelemzés, alkalmazkodás) csökkent érvényesülése volt jellemző. A fentieket figyelembe véve tehát valószínü, hogy a cyanoticus állapot befolyásolja ugyan a pszichés fejlődést, de nem tekinthető kizárólagosnak: egyéb faktorok és körülmények szintén szerepet játszanak a viselkedésjellemzők alakulásában. Ezen megfigyelést támasztják alá az irodalmi adatok is: a cyanoticus állapot erős, de nem az egyetlen befolyásoló faktora a pszichológiai fejlődésnek, így az egyéb perioperatív állapotok számbavétele szükséges.

A többszörös mútéten átesetteknél szintén rosszabb kimenetel várható a pszichés fejlődés terén [9]. A múttétek magasabb száma rontja az érzelmi adaptációt és fokozza a viselkedési diszreguláció kialakulásának veszélyét, fóleg akkor, ha ezekre nem tervezetten kerül sor [9, 37]. A fentieket a jelen vizsgálatban megfigyeltek is megerősítik, ugyanis a tervezett reoperáción átesettekben volt megfigyelhetô a leginkább a menekülö-elkerülő magatartásforma, illetve igen alacsonynak bizonyul esetükben a problémamegoldó megküzdés mozgósítására való hajlam is. A mútéti beavatkozások magasabb száma együtt jár sorozatos hospitalizációval, így összességében hosszabb kórházi tartózkodással, ami főként kisgyermekkorban akut módon szeparációs szorongást, hosszú távon az anya-gyermek kapcsolat sérülését, így akár kapcsolati zavarokat, a társas érintkezés deficitjét hozhatja magával, s ez táptalaja lehet különféle belső pszichés és magatartásbeli problémáknak. Általában a kórházi tartózkodás, de különösen a hosszasabb intenzív osztályos tartózkodás olyan mértékű kiszolgáltatottsággal és sérülékenységgel jár együtt, ami feltételezésünk szerint tanult tehetetlenséget indukálhat, melyben a 'coping' mechanizmusok aktiválási hajlandósága sérülhet. Mindezek mellett a beteg gyermek védelme, túlóvása is okozhatja a megküzdési módok elsajátításának és használatának deficitjét $[15,37,38]$. Az igazán gyermekközpontú ellátás biztosítása nehéz, de mindenképp része a gyermekek bevonása a pszichológiai felmérésbe. Az irodalomban fellelhető vizsgálatok legfóképp a szülői vagy a tanítói rálátást elemzik, kihagyva a gyermek önjellemző értékelését $[36,38]$. Vizsgálatunk nagy előnye, hogy a gyermek perspektívája mentén is próbál rávilágítani a pszichológiai állapotra, feltárva ezzel a gyermek önpercepcióját. A gyermekek megküzdési mechanizmusainak vizsgálatában az önértékelő kérdő́ív igen informatívnak bizonyult.

\section{Korlátok}

A korai sebészeti beavatkozások természetesen nem tehetők teljes egészében felelőssé a későbbi pszichológiai fejlődés zavarainak kialakulásáért: genetikai faktorok, a szociális és családi környezet mind felelősek az egyén pszichológiai integritásának fenntartásáért, melyekre vizsgálatunk egyelőre nem terjedt ki, beleértve a szülőgyermek kapcsolat részletes feltárását és elemzését. Korlátunk az egycentrumos vizsgálati jelleg és az alacsony mintaelemszám, bár ahogy a statisztikai elemzésből kitû́nik, a hatásméret-mutatók (Cohen-d) a legtöbb teszteredmény esetén viszonylag alacsony vagy közepes szintet értek el, vagyis úgy tünik, igen kicsi a valószínúsége annak, hogy a kis mintaelemszám torzító hatása okozná a nem szignifikáns eredményeket. Populációnk heterogenitása a vitiumokat illetően szintén limitáló tényező, de az ezzel kapcsolatos, szakirodalomban fellelhető közlemények egy része is széles problémaskálán mozgó betegcsoportot mutat be $[39,40]$. A heterogenitás okozta torzító hatást igyekeztünk a lehetô leghatékonyabban csökkenteni azzal, hogy az operált gyermekek csoportján belül elkülönítve vizsgáltunk a vitium alapján két, leginkább homogénnek tekinthető betegcsoportot. A jövőben a betegek anomália szerinti felosztása révén még informatívabb képet kaphatunk a hosszú távú pszichés állapotot befolyásoló faktorokról. Végül pedig megemlítendő, hogy nem álltak rendelkezésünkre a peripartum periódusra vonatkozó adatok, melyek ismerten jelentős hatással bírnak a fejlődésre (intrauterin sorvadás, az anya szorongása, dohányzási szokásai vagy élvezeti szer használata, teratogén faktorok, a szülés körülményei stb.) [41, 42]. Nem kerültek regisztrálásra teljes egészében az életkörülményekre jellemző változók és a családi háttér sem.

\section{Következtetés}

A jelen tanulmány a szívsebészeti beavatkozáson átesett gyermekek későbbi megküzdési és viselkedéses múködését vizsgálja. Bár nehezen feltárható ok-okozati összefüggésekkel állunk szemben, a mútétek neurológiai, ezen keresztül pedig pszichológiai következményei semmiképp nem elhanyagolhatók. A szívsebészeti beavatkozások jelentősen befolyásolják a késóbbi viselkedésfejlódést. Úgy tûnik, hogy a kialakult maladaptív viselkedési mechanizmusok jellege jelentősen függ az inkomplett keringés fennállásának időtartamától, a mútétek számától és a kórházi tartózkodás hosszától. A maladaptív megküzdés legfő́képp csökkent érzelem- vagy problémaközpontú válaszkészségben, a szomatizációs tendenciák felerősödésében és a menekülő-elkerülő magatartásforma felerősödésében nyilvánul meg. Az általunk használt tesztek felvétele egyszerú és gyors, a nyert információ szerepe a korai diagnosztikában igen hasznos, és a prognózis megbecsülésében nyújthat segítséget. Nyilvánvaló, hogy egy életet veszélyeztető rendellenesség sebészi korrekciója és a perioperatív komplikációk elkerülése vagy szükségszerú megoldása minden esetben előnyt élvez. Ha azonban az élet fenntartása sikeres, és a vitális funkciók jól múköönek, a pszichés faktorok is előtérbe kerülnek, melyeket figyelmen kívül hagyni a későbbi intellek- 
tuális fejlődésre, szociális beilleszkedésre és az egyén teljes egészségére való tekintettel nem szabad. További befolyásoló faktorok feltárása segíthet megérteni a kora gyermekkori szívsebészeti beavatkozást követő viselkedésváltozások pszichopatológiáját, aminek jelentősége társadalmi szinten sem elhanyagolható.

Anyagi támogatás: A kutatómunka és a közlemény megírása anyagi támogatásban nem részesült.

Szerzöi munkamegosztás: C. N. R.: Adatgyüjtés, adatelemzés, pszichológiai felmérés és analízis, a cikk megírása. O. Zs.: Adatgyưjités, adatelemzés, a kézirat megírása. Cs. M.: Kritikai észrevételezés, a kézirat érvényesítése. K. T. B.: Kritikai észrevételezés, a kézirat jóváhagyása. R. Gy.: Adatgyújtés, pszichológiai felmérés, statisztikai elemzés. A. L.: Adatgyưijtés, adatelemzés, a kézirat végleges változatának jóváhagyása. Sz. E.: Adatelemzés, kritikai észrevételezés, a végleges verzió jóváhagyása, átirata. G. J.: Kritikai észrevételezés, a végleges verzió jóváhagyása. Sz. A.: A vizsgálati protokoll és a kivitelezés tervezése, adatelemzés, pszichológiai felmérés, a kézirat megírása. A cikk végleges változatát valamennyi szerző elolvasta és jóváhagyta.

\section{Érdekeltségek: A szerzőknek nincsenek érdekeltségeik.}

\section{Irodalom}

[1] Khairy P, Ionescu-Ittu R, Mackie AS, et al. Changing mortality in congenital heart disease. J Am Coll Cardiol. 2010; 56: 11491157.

[2] De Frances CJ, Cullen KA, Kozak LJ. National Hospital Discharge Survey: 2005 annual summary with detailed diagnosis and procedure data. Vital Health Stat 13. 2007; 165: 1-209.

[3] Marino BS, Lipkin PH, Newburger JW, et al. Neurodevelopmental outcomes in children with congenital heart disease: evaluation and management: a scientific statement from the American Heart Association. Circulation 2012; 126: 1143-1172.

[4] Wilder RT, Flick RP, Sprung J, et al. Early exposure to anesthesia and learning disabilities in a population-based birth cohort. Anesthesiology 2009; 110: 796-804.

[5] Gaynor JW, Stopp C, Wypij D, et al. Neurodevelopmental outcomes after cardiac surgery in infancy. Pediatrics 2015; 135: 816-825.

[6] Daliento L, Mapelli D, Russo G, et al. Health related quality of life in adults with repaired tetralogy of Fallot: psychosocial and cognitive outcomes. Heart 2005; 91: 213-218.

[7] Lane DA, Lip GYH, Millane TA. Quality of life in adults with congenital heart disease. Heart 2002; 88: 71-75.

[8] Bellinger DC, Wypij D, Kuban KC, et al. Developmental and neurological status of children at 4 years of age after heart surgery with hypothermic circulatory arrest or low-flow cardiopulmonary bypass. Circulation 1999; 100: 526-532.

[9] Areias ME, Pinto CI, Vieira PF, et al. Long term psychosocial outcomes of congenital heart disease in adolescents and young adults. Zhongguo Dang Dai Er Ke Za Zhi (Chin J Contemp Pediatr.) 2013; 15: 810-816. [Chinese]

[10] Utens E, Amianto F. Long-term psychosocial functioning in congenital heart disease children and adolescents and in their parents. Minerva Pediatr. 2015; 67: 2-28. [Italian]
[11] Hövels-Gürich HH, Konrad K, Skorzenski D, et al. Long-term behavior and quality of life after corrective cardiac surgery in infancy for tetralogy of Fallot or ventricular septal defect. Pediatr Cardiol. 2007; 28: 346-354.

[12] Bellinger DC, Newburger JW, Wypij D, et al. Behaviour at eight years in children with surgically corrected transposition: the Boston Circulatory Arrest Trial. Cardiol Young 2009; 19: 86-97.

[13] Utens EM, Verhulst FC, Meijboom FJ, et al. Behavioural and emotional problems in children and adolescents with congenital heart disease. Psychol Med. 1993; 23: 415-424.

[14] DeMaso DR, Beardslee WR, Silbert AR, et al. Psychological functioning in children with cyanotic heart defects. J Dev Behav Pediatr. 1990; 11: 289-294.

[15] Ludman L, Lansdown R, Spitz L. Effects of early hospitalization and surgery on the emotional development of 3 year olds: an exploratory study. Eur Child Adolesc Psychiatry 1992; 1: 186195.

[16] Suls J, Fletcher B. The relative efficacy of avoidant and nonavoidant coping strategies: a meta-analysis. Health Psychol. 1985; 4: 249-288.

[17] Andonian C, Beckmann JR, Biber S, et al. Current research status on the psychological situation of adults with congenital heart disease. Cardiovasc Diagn Ther. 2018; 8: 799-804.

[18] Mahle WT, Wernovsky G. Long-term developmental outcome of children with complex congenital heart disease. Clin Perinatol. 2001; 28: 235-247.

[19] Ferguson TB Jr, Dziuban SW Jr, Edwards FH, et al. The STS National Database: current changes and challenges for the new millennium. Committee to Establish a National Database in Cardiothoracic Surgery, The Society of Thoracic Surgeons. Ann Thorac Surg. 2000; 69: 680-691.

[20] Achenbach TM, Ruffle TM. The Child Behavior Checklist and related forms for assessing behavioral/emotional problems and competencies. Pediatr Rev. 2000; 21: 265-271.

[21] Gádoros J. Investigation of sociodemographic risk factors with child behaviour checklist. [Szociodemográfiai rizikótényezők vizsgálata gyermek viselkedési kérdőív alkalmazásával.] Psychiatr Hung. 1996; 11: 147-166. [Hungarian]

[22] Lazarus RS, Folkman S. Coping and adaptation. In: Gentry WD. (ed.) The handbook of behavioral medicine. Guilford Press, New York, NY, 1984; pp. 282-325.

[23] Kopp MS, Skrabski Á, Szedmák S. Socioeconomic factors, severity of depressive symptomatology, and sickness absence rate in the Hungarian population. J Psychosom Res. 1995; 39: 10191029.

[24] Rózsa S, Purebl G, Susánszky É, et al. Dimensions of coping: Hungarian adaptation of the Ways of Coping Questionnaire. [A megküzdés dimenziói: A Konfliktusmegoldó Kérdőív hazai adaptációja.] Mentálhig Pszichoszomat. 2008; 9: 217-241. [Hungarian]

[25] Namachivayam P, Taylor A, Montague T, et al. Long-stay children in intensive care: long-term functional outcome and quality of life from a 20-yr institutional study. Pediatr Crit Care Med. 2012; 13: 520-528.

[26] Solla F, Tran A, Bertoncelli D, et al. Why a p-value is not enough. Clin Spine Surg. 2018; 31: 385-388.

[27] Ternestedt BM, Wall K, Oddsson H, et al. Quality of life 20 and 30 years after surgery in patients operated on for tetralogy of Fallot and for atrial septal defect. Pediatr Cardiol. 2001; 22: 128-132.

[28] Spijkerboer AW, Utens EM, Bogers AJ, et al. Long-term behavioural and emotional problems in four cardiac diagnostic groups of children and adolescents after invasive treatment for congenital heart disease. Int J Cardiol. 2008; 125: 66-73.

[29] Delvecchio E, Salcuni S, Lis A, et al. Hospitalized children: anxiety, coping strategies, and pretend play. Front Public Health $2019 ; 7: 250$. 
[30] Dahlawi N, Milnes LJ, Swallow V. Behaviour and emotions of children and young people with congenital heart disease: a literature review. J Child Health Care 2020; 24: 317-332.

[31] Kasmi L, Bonnet D, Montreuil M, et al. Neuropsychological and psychiatric outcomes in dextro-transposition of the great arteries across the lifespan: a state-of-the-art review. Front Pediatr. 2017; 5: 59

[32] Hövels-Gürich HH, Konrad K, Skorzenski D, et al. Attentional dysfunction in children after corrective cardiac surgery in infancy. Ann Thorac Surg. 2007; 83: 1425-1430.

[33] Sarrechia I, Miatton M, François K, et al. Neurodevelopmental outcome after surgery for acyanotic congenital heart disease. Res Dev Disabil. 2015; 45-46: 58-68.

[34] Johnson B. Behaviour problems in children with congenital heart disease. BMH Med J. 2015; 2: 14-19.

[35] Birkeland AL, Rydberg A, Hägglöf B. The complexity of the psychosocial situation in children and adolescents with heart disease. Acta Paediatr. 2005; 94: 1495-1501.

[36] DeMaso DR, Snell C. Promoting coping in children facing pediatric surgery. Semin Pediatr Surg. 2013; 22: 134-138.

[37] Levert EM, Helbing WA, Dulfer K, et al. Psychosocial needs of children undergoing an invasive procedure for a $\mathrm{CHD}$ and their parents. Cardiol Young 2017; 27: 243-254.

[38] Söderbäck M, Coyne I, Harder M. The importance of including both a child perspective and the child's perspective within health care settings to provide truly child-centred care. J Child Health Care 2011; 15: 99-106.

[39] Menahem S, Poulakis Z, Prior M. Children subjected to cardiac surgery for congenital heart disease. Part 1 - emotional and psychological outcomes. Interact Cardiovasc Thorac Surg. 2008; 7 : 600-604.

[40] Pike NA, Woo MA, Poulsen MA, et al. Predictors of memory deficits in adolescents and young adults with congenital heart disease compared to healthy controls. Front Pediatr. 2016; 4: 117.

[41] Nagy A, Beke AM, Cserjési R, et al. Follow-up study of extremely low birth weight preterm infants to preschool age in the light of perinatal complications. [Az extrém kis születési súlyú koraszülöttek fejlődésének követése az óvodáskor végéig a perinatalis szövődmények tükrében.] Orv Hetil. 2018; 159: 16721679. [Hungarian]

[42] Turai R, Schandl MF, Dergez T, et al. Early and late complications of hyperglycemic extremely low birth-weight infants. $[\mathrm{Az}$ extrém alacsony születési súlyú koraszülöttek hyperglykaemiájának korai és késői szövődményei]. Orv Hetil. 2019; 160: 12701278. [Hungarian]

(Czobor Nikoletta Ráhel dr., Budapest, Róbert Károly krt. 44., 1134 e-mail: czobor.nikoletta@gmail.com)

\title{
Az Orvosi Hetilap 2020; 161: 1540. oldalán (36. szám) megjelent OH-Kvízre
} három helyes megfejtés érkezett.

\author{
A beküldők: Dr. Bíró László (Budapest), Dr. Kónya Csaba (Budapest) \\ és Dr. Somogyi Erzsébet (Budapest).
}

A nyerteseknek szívből gratulálunk.

Nyereményüket - egy, az Akadémiai Kiadó webáruházában kedvezményes vásárlásra jogosító kupont - e-mailen küldjük el.

A cikk a Creative Commons Attribution 4.0 International License (https://creativecommons.org/licenses/by/4.0/) feltételei szerint publikált Open Access közlemény, melynek szellemében a cikk bármilyen médiumban szabadon felhasználható, megosztható és újraközölhető, feltéve, hogy az eredeti szerző és a közlés helye, illetve a CC License linkje és az esetlegesen végrehajtott módositások feltüntetésre kerülnek. (SID_1) 